\title{
Algoritma Genetika untuk Mengoptimasi Penjadwalan Pembersihan Jaringan Penukar Panas
}

\author{
Totok Ruki Biyanto ${ }^{*}$
}

\begin{abstract}
The resulting MINLP problem is very complex and finding the global optimum is a challenging task. Solving this problem can use two methods, namely deterministic and metaheuristic. Deterministic method requires enough knowledge to determine areas that can provide global optimum solution. This method sometime provide unconvergen solution. Another method is metaheuristic method that simple and promising global optimum solution without introducing any approximations or simplifying assumptions. This method works without influenced by the previous optimization results. One of metaheuristic algorithms is Genetic Algorithm (GA). In this paper, the GA will be used to solve the optimization of cleaning schedule of Heat Exchanger Network (HEN) in a refinery Crude Preheat Train (CPT). The results showed that efficiency of HEN 23\% increased which can be translated in IDR 14.1 Billion of fuel saving. Metaheuristic algorithm always provide a solution at the end of optimization's iteration and it can be run continuesly in order to get more optimal solution.
\end{abstract}

Keywords: MINLP, Metaheuristic, Genetic Algorithm, Heat Exchanger Network.

\section{Pendahuluan}

Engineering Sciences Data Unit (ESDU) melaporkan bahwa fouling pada Jaringan Penukar Panas (JPP) di refineri atau Crude Preheat Train (CPT) adalah masalah serius yang belum tepecahkan (ESDU [1]), yang menyebabkan peningkatan konsumsi energi dan menghabiskan triyunan dollar per tahun. Untuk sebuah unit refineri dengan kapasitas $100,000 \mathrm{bbl} / \mathrm{hari}$, penurunan coil inlet temperature (CIT) karena fouling sebesar $1 \mathrm{~K}$ menyebabkan sekitar £ 25,000 untuk penambahan biaya bahan bakar yang harus dibakar dan sekaligus penambahan 750te karbon dioksida pertahun (Yeap [2]). Berdasarkan pertimbangan secara ekonomi dan lingkungan tersebut, maka untuk mengurangi efek fouling adalah melakukan pembersihan JPP secara berkala. (Smaili et al. [3]; Georgiadis et al. [4]; Lavaja et al. [5]; Markowski et al. [6]; Sanaye et al. [7]; Georgiadis et al. [8]).

Namun, terlalu sering dibersihkan akan menambah biaya pembersihan/perawatan, sebaliknnya, jika tidak dibersihkan akan kehilangan banyak energi dan masalah lingkungan. Optimasi jadwal pembersihan wajib dilakukan. Optimasi jadwal pembersihan bertujuan untuk menentukan berapa banyak pembersihan pada setiap penukar panas dalam periode yang ditinjau, yang dipengaruhi oleh biaya pembersihan, energi yang hilang saat pembersihan dan energi yang direkoveri.

\footnotetext{
${ }^{1}$ Fakultas Teknologi Industri, Jurusan Teknik Fisika, Institut Teknologi Sepuluh Nopember, Kampus ITS Sukolilo Surabaya 60111.Email: trb@ep.its.ac.id

* Penulis korespondensi
}

Optimasi ini memerlukan tiga komponen yaitu model JPP yang terpercaya, model fouling yang valid dan teknik optimisasinya (Smaïli et al. [3]; Sanaye et al. [7]; Georgiadis et al. [8]).

Model JPP yang biasanya dipakai adalah lumpedparameter model (Ishiyama et al. [9]). Model fouling bisa dimodelkan dengan beberapa metode. Model regresi (Smailli et al. [3]; Sanaye et al. [7]; Georgiadis et al. [8]), model semi-empirikal (seperti model Panchal [9]) atau Jaringan Saraf Tiruan (JST) (Riverol et al. [10], Lalot [11], Aminian et al. [12,13], Smaili et al. [14]) adalah pemodelan yang biasa dipakai. Namun untuk tujuan penjadwalan pembersihan biasanya model linear dan asimtotik adalah yang di pakai regresi (Smaili, et al. [3]; Sanaye et al. [7], Georgiadis et al. [8]). JST digunakan untuk memprediksinya, karena ketidaklinearan fouling (Riverol et al. [10], Lalot [11] Aminian et al. [12,13]).

Optimasi jadwal pembersihan masuk dalam kelas Mixed Integer Non-Linear Programming (MINLP) karena mengandung dua tipe variable yaitu diskrit dan kontinu yang nonlinear Lavaja et al. [5] Markowski et al. [6], Georgiadis et al. [8], Smaili et al. [14]. Sering kali model menghasilkan non konvek output, sehingga tidak menjamin solusi yang globaloptimum.

Beberapa teknik optimasi telah digunakan untuk memecahkan masalah optimasi penjadwalan pembersihan. Kompleksitas masalah MINLP tergantung pada bentuk fungsi tujuan. Optimasi jadwal pembersihan memiliki multi-atribut tujuan yaitu memaksimalkan penghematan energi untuk diambil dan meminimalkan biaya pembersihan. Kadang- 
kadang model yang digunakan menghasilkan nonkonvek output. Oleh karena itu, solusi yang globaloptimal belum tentu tercapai. Masalah MINLP adalah NP-complete, yaitu termasuk dalam kelas masalah sulit secara teoritis dan karena itu sangat sulit untuk dipecahkan. Ini menginspirasi (Georgiadis et al. [4]) untuk menyederhanakan model nonlinear menjadi linear dan dipecahkan dengan menggunakan MILP. Tentu saja, akurasi dari model linear lebih rendah dibandingkan dengan model nonlinear. Berkenaan dengan masalah di atas, dan mempertimbangkan bahwa jadwal pembersihan setiap penukar panas dipengaruhi oleh jadwal pembersihan penukar panas yang lain di dalam JPP, maka MILP baru diusulkan oleh Lavaja et al. (Lavaja et al. [5]). Dalam pendekatan ini, model didekomposisi dan diselesaikan secara berurutan. Prosedur ini menghasilkan penghematan energi yang lebih baik di pabrik yang sama dibandingkan demgan metode yang digunakan dalam karya (Smaïli et al. [3]). Oleh karena itu, teknik untuk menangani nonlinear dan kompleksitas MINLP diperlukan.

Dalam rangka mencapai solusi global optimal, penelitian sebelumnya telah menggunakan algoritma tertentu untuk memecahkan masalah MINLP seperti branch and bound (BB), generalized benders decomposition (GBD) dan outer approximation (OA) yang tersedia dalam paket perangkat lunak komersial. Dalam rangka untuk membuat linearisasi dan dekomposisi model, metode ini membutuhkan pengetahuan dari sistem yang akan dioptimalkan.

Genetic Algorithm (GA) adalah teknik yang menjanjikan untuk memecahkan masalah MINLP nonlinear dan kompleks. Ini telah digunakan untuk optimasi pada masalah teknik kimia antara lain penjadwalan batch plant (Smaili et al. [17]), desain yang optimal dari penukar panas (Tayal et al. [18]), optimasi fermentasi glukosa menjadi asam glukonat (Cheema et al. [19]), pemeliharaan penjadwalan dalam sistem tenaga (Negnevitsky et al. [20]), penjadwalan sumber daya (Syswerda et al. [21]), optimasi penjadwalan proses kilang (Sim et al. [22]), dan penjadwalan kedatangan minyak mentah (Guy et al. [23]). Secara umum, GA adalah teknik optimasi yang paling efisien dalam hal evaluasi fungsi. Solusi dari masalah MINLP menggunakan GA telah terbukti menjadi pendekatan yang valid untuk masalah nonkonvek di mana waktu komputasi tidak menjadi masalah (Costa et al. [16]).

Oleh karena, masalah optimasi ini termasuk sebagai masalah MINLP, dimana masalah MINLP secara umum adalah non-konvek dengan banyak lokal optimum. Metode konvensional tidak menjamin solusi global optimal karena non-konvek output dan kompleksitas sistem, dan bahkan ada kemungkinan akan tidak ada hasil yang diharapkan pada akhir optimasi. Kondisi tersebut memicu penggunaan teknik optimasi seperti Genetic Algorithm (GA) untuk pemecahan optimasi jadwal pembersihan JPP yang menjamin hasil yang mendekati global optimum akan diteliti.

\section{Metode Penelitian}

\section{Crude Preheat Train (CPT)}

JPP yang dipelajari adalah sebuah CPT yang berisi sebelas penukar panas pada sebuah refineri. Setiap penukar panas mempunyai multiple shell yang tergabung secara seri dan/atau paralel, seperti terlihat pada Gambar 1. Data diambil dari plant historian dalam Distributed Control System (DCS) meliputi 81 tag number selama empat tahun. Data terdiri dari temperatur, laju aliran dan properti masing-masing fluida pada penukar panas. Data diproses untuk merekoveri data yang hilang, membuang data outlier dan data rekonsiliasi.

Untuk membangun optimasi jadwal pembersihan diperlukan tiga komponen yaitu model CPT, Model fouling dan metode optimasinya. Kebanyakan simulasi penukar panas menggunakan lumped-parameter model (Ishiyama [9]). Performansi penukar panas dihitung dengan persamaan-persamaan berikut ini;

$Q=U_{a} A F \Delta T_{L M}$

dimana:

$Q \quad$ : beban kalor

$U_{a}$ : aktual koefisuen perpindahan panas keseluruhan

A : luasan heat transfer

$F \quad$ : faktor koreksi untuk LMTD

$\Delta T_{L M}:$ Log Mean Temperature Difference (LMTD)

Kalor pada penukar panas haruslah seimbang antara fluida yang panas dan dingin, oleh sebab itu data rekonsiliasi diperlukan.

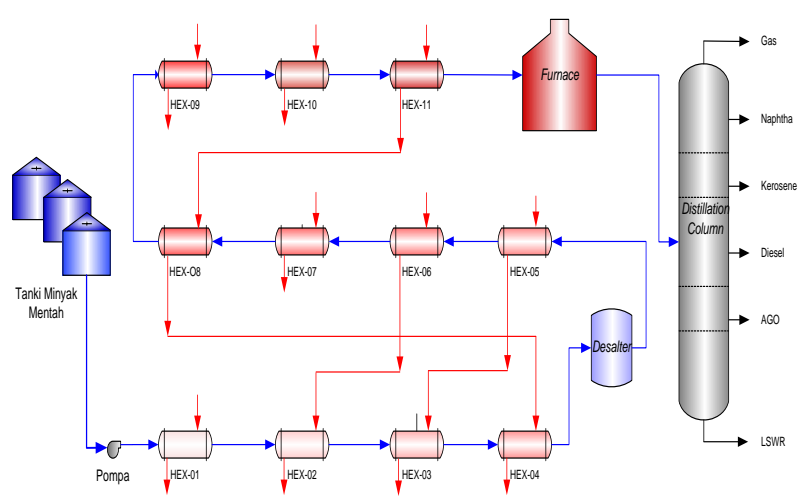

Gambar 1. Skematik diagram dari CPT 
$Q=m_{c} C p_{c} \Delta T_{c}=m_{h} C p_{h} \Delta T_{h}$

dimana:

$m$ : massa fluid

$C p$ : kapasitas panas

$T c$ : temperature fluida dingin

$T h$ : temperature fulida panas

Hubungan koefisien perpindahan panas keseluruhan dan fouling bisa ditulis sebagai berikut:

$\frac{1}{U_{a}}=\frac{1}{U_{o}}+R_{f}$

$\frac{1}{U_{a}}=\frac{d_{o}}{d_{i} h_{i}}+\frac{d_{o} \ln \left(d_{o} / d_{i}\right)}{2 K_{w}}+\frac{1}{h_{o}}$

dimana:

$R_{f}:$ resistansi fouling

$h_{i}$ : koefesien perpindahan panas pada tube-side film

$h_{o}$ : koefesien perpindahan panas pada shell-side film

$U_{o}$ : aktual koefisien perpindahan panas keseluruhan

$K_{w}:$ konduktifitas panas dari dinding tube

$d_{o}:$ diameter terluar dari tube

$d_{i}$ : diameter dalam dari tube

Mengunakan persamaan-persamaan di atas maka dapat dihitung temperatur luaran dari penukar panas sebagai berikut (Sanaye et al. [7]; Ishiyama [9]):

$$
\begin{aligned}
T_{c, 0}= & {\left[\frac{k_{1}\left(\exp \left(\left(-k_{2} F\left(k_{1}-1\right)\right)-1\right)\right.}{\exp \left(-k_{2} F\left(k_{1}-1\right)-k_{1}\right.}\right] T_{h, i}+} \\
& {\left[\frac{\left(1-k_{1}\right) \exp \left(\left(-k_{2} F\left(k_{1}-1\right)\right)\right.}{\exp \left(-k_{2} F\left(k_{1}-1\right)-k_{1}\right.}\right] T_{c, i} } \\
T_{h, 0}= & {\left[\frac{\exp \left(\left(-k_{2} F\left(k_{1}-1\right)\right)-1\right.}{\exp \left(-k_{2} F\left(k_{1}-1\right)-k_{1}\right.}\right] T_{c, i}+} \\
& {\left[\frac{\left(k_{1}-1\right)}{\exp \left(-k_{2} F\left(k_{1}-1\right)-k_{1}\right.}\right] T_{c, i} }
\end{aligned}
$$

dimana:

$k_{1}=\frac{m_{h} C_{p, h}}{m_{c} C_{p, c}}$

$k_{2}=\frac{U A}{m_{h} C_{p, h}}$

Fouling merupakan fenomena yang komplek, keberadaannya tergantung pada kondisi operasi, geometri peralatan dan properti dari fluida. Pada peneiltian ini fouling diprediksi menggunakan persamaan sederhana (Kern and Seaton [24]), yang merupakan fungsi exponensial yag berbeda-beda untuk setiap peralatan penukar panas. Persamaan ini bisa ditulis sebagai berikut:
$R_{f}(t)=a\left(1-e^{-b t}\right)$

dimana:

$R_{f} \quad$ : resistansi fouling

$a, b$ : konstanta hasil fitting data untuk masingmasing penukar panas

Jumlah pembersihan atau bisa ditulis sebagai interval pembersihan dan jadwal pembersihan, diperoleh dengan memaksimalkan fungsi tujuan sebagai berikut: (Lavaja et al [5]).

$$
\begin{aligned}
\min J= & \sum_{p=1}^{N_{p}} \sum_{n=1}^{N_{E}} C_{E} y_{n, p}\left(Q_{n, c}-Q_{n, p}\right) \Delta t- \\
& \sum_{p=1}^{N_{p}} \sum_{n=1}^{N_{E}} C_{c l}\left(1-y_{n, p}\right)
\end{aligned}
$$

dimana:

$C_{E}$ : biaya energy

$C_{c l}:$ biaya pembersihan

$N_{E}$ : jumlah penukar panas dalam JPP

$Q$ : beban kalor

$y$ : status dari masing-masing penukar panas, 1 jika unit bekerja dan 0 jika unit tidak bekerja

$n: 1,2 \ldots N_{E}$ nomor penukar panas

$c$ : periode operasi kondisi bersih

$p$ : periode operasi kondisi teroptimasi

$i$ : inlet

$o$ : outlet

Persamaan di atas dipengaruhi oleh dua komponen biaya yaitu biaya pembersihan $\left(C_{c l}\right)$ yang tergantung dari ukuran penukar panas dan biaya energi $\left(C_{E}\right)$. Dalam aplikasi ini lama pembersihan adalah lima hari, dimana penukar panas akan di-bypass. Periode yang ditinjau dalam optimasi jadual pembersihan ini adalah 4 tahun dan diskritisasi waktu $(\Delta t)$ dilakukan untuk selang 30 hari.

\section{GA untuk optimasi penjadualan pembersihan penukar panas dalam JPP}

Dalam rangka memecahkan permasalahan MINLP pada penjadualan pembersihan JPP, GA sederhana digunakan untuk memberikan solusi optimum pada 11 penukar panas seperti pada Gambar 1, dengan meminimumkan fungsi tujuan pada Persamaan 10. Periode jadual pembersihan diperkirakan antara 1 bulan sampai 32 bulan sekali yang direpresentasikan dalam 5 bit koromosom seperti pada Tabel 1 . Jadi untuk keseluruhan 11 penukar panas dalam JPP jumlah bit total adalah 55 bit. Nilai fitness didapat dengan mensimulasikan JPP (Persamaan 1 10) dalam kondisi fouling dengan berbagai skenario pembersihan dalam satu frame waktu dari 0 sampai $t_{F}$.

Langkah-langkah untuk solusi optimisasi penjadualan pembersihan JPP bisa dijelaskan secara singkat 
sebagai berikut:

L1 GA membuat sebuah 100 individu dalam sebuah polulasi yang masing-masing terdiri dari 5 bit dan diisi secara random.

L2 Menghitung fitness untuk semua penukar panas dalam JPP dalam kondisi bersih dan kotor menggunakan Persamaan 10 .

L3 Proses GA sederhana

a. Pemilihan pasangan individu yang akan di jadikan orang tua menggunakan roulete wheel.

b. Proses kawin pada GA mengunakan satu titik perkawinan (point crossover) dengan $P_{c}=$ 0,7 (Probabilitas kawin) maka pasangan orang tua akan terpilih secara random. Jika terakhir hanya ada satu individu, maka individu tersebut akan disalin dan dikawinkan dengan salinan yang telah dibuat.

c. Mutasi kedua anak pada lokus mengunakan flip mutasi dengan $P_{m}=0,001$ (probabilitas mutasi) dan dari hasil mutasi ini akan menjadi polulasi yang baru.

L4 Ganti polulasi lama dengan populasi yang baru.

L5 Menghitung nilai fitness mengunakan Persamaan 10 untuk stiap kromosom dalam populasi

L6 Mekanisme elitsm akan menyimpan 5\% individu yang mempunyai fitness terbaik. Sisanya yang $95 \%$ akan diproses oleh GA secara normal melalui proses seleksi, kawin dan mutasi.

L7 Kriteria berhenti. Jika generasi mencapai 100 generasi, maka proses optimasi dihentikan. Ini bisa diartikan kondisi optimum telah tercapai, karena pada optimasi sistem ini hasil-hasil yang mendekati global optimum sudah mulai tercapai saat generasi 40 atau sekitar iterasi 4000 karena dalam satu generasi ada 100 indvidu, seperti terlihat pada Gambar 6. Selanjutnya hasil optimasi akan disimpan dan jika tidak, maka kembali ke L3.

Tabel 1. Periode pembersihan yang mungkin untuk sebuah penukar panas

\begin{tabular}{ccccccc}
\hline \multicolumn{4}{c}{ Biner } & & Desimal & Periode pembersihan \\
\hline 0 & 0 & 0 & 0 & 0 & 0 & Tanpa pembersihan \\
0 & 0 & 0 & 0 & 1 & 1 & 1 \\
0 & 0 & 0 & 1 & 0 & 2 & 2 \\
& & & & & $\bullet$ & \\
& & & & & $\bullet$ & \\
1 & 1 & 1 & 1 & 1 & 31 & 31 \\
\hline
\end{tabular}

Tabel 2. Fenotip hasil optimasi GA berupa interval pembersihan

E-01 E-02 E-03 E-04 E-05 E-06 E-07 E-08 E-09 E-10 E-11

\begin{tabular}{lllllllllll}
15 & 24 & 25 & 23 & 9 & 28 & 26 & 5 & 17 & 5 & 29 \\
\hline
\end{tabular}

\section{Hasil dan Pembahasan}

Masalah MINLP pada kasus menentukan jadwal pembersihan yang optimal untuk semua penukar panas di JPP secara serentak diselesaikan dengan menggunakan GA. Seperti telah dibahas sebelumnya bahwa ukuran, nonlinear, kompleksitas dan keberadaan variabel kontinu dan diskrit pada masalah optimasi ini memerlukan penggunaan GA untuk memecahkannya. Fungsi biaya termasuk biaya kehilangan energi karena fouling dan pembersihan, biaya pembersihan yang beragam mengikuti ukuran, dan biaya tambahan karena penambahan tekanan yang ditanggung pompa karena fouling dipertimbangkan dalam penelitian ini.

GA mulai bekerja dengan membuat sebuah generasi yang terdiri dari 100 kromosom dengan genotip yang dipilih secara acak dan selanjutnya akan diproses mengikuti algoritma seleksi, kawin, mutasi, elitism, sampai 100 iterasi, dan menghasilkan evolusi 10000 fitness pada 100 kromosom sepanjang iterasi seperti terlihat pada Gambar 6. Solusi optimal penjadwalan pembersihan untuk semua penukar panas yang diperoleh pada akhir iterasi, ditunjukkan pada Tabel 2. Tabel 2 adalah fenotip berupa interval pembersihan dalam satuan bulan. Terlihat bahwa semua penukar panas harus dibersihkan dalam perode tertentu, dimulai E-08 dan E-10 yang paling sering dibersihkan (setiap 5 bulan) sampai E-11 yang paling jarang dibersihkan (setiap 29 bulan).

Elitsm telah menyimpan fenotipe terbaik hasil GA sepanjang generasi. Fenotip terbaik memiliki nilai fitness yang mampu menurunkan energi yang hilang saat kondisi optimal sebesar IDR 48,1 Milyar sehingga menghasilkan penghematan sebesar IDR 14,1 Milyar atau kenaikan effisiensi 23\% selama periode 44 bulan. Penghematan biaya sebesar 23\% dihitung dari potensi energi maksimum (teoritis). Kontribusi masing-masing penukar panas dalam pengambilan energi saat kondisi jadwal pembersihan yang optimal ditunjukkan pada Tabel 3.

Penukar panas E-01 dibersihkan dua kali selama periode 44 bulan dan itu mampu mengurangi kerugian dari IDR 18,7 Milyar pada kondisi kotor dimana JPP tidak dibersihkan sama sekali selama 44 bulan. Kerugian bila dibandingkan dengan kondisi tidak ada pembersihan yaitu IDR 7,6 Milyar, maka penghematan sebesar IDR 11,1 Milyar dicapai oleh satu penukar panas saja dan harus dicatat di sini bahwa tidak ada efek interaksi pada penukar panas dalam segala kondisi operasi.

Penukar panas E-05 menjalani 4 pembersihan dan telah mengurangi kerugian bersih dari IDR 8,2 Milyar menjadi IDR 3,6 Milyar menghasilkan penghematan IDR 4,9 Milyar. 


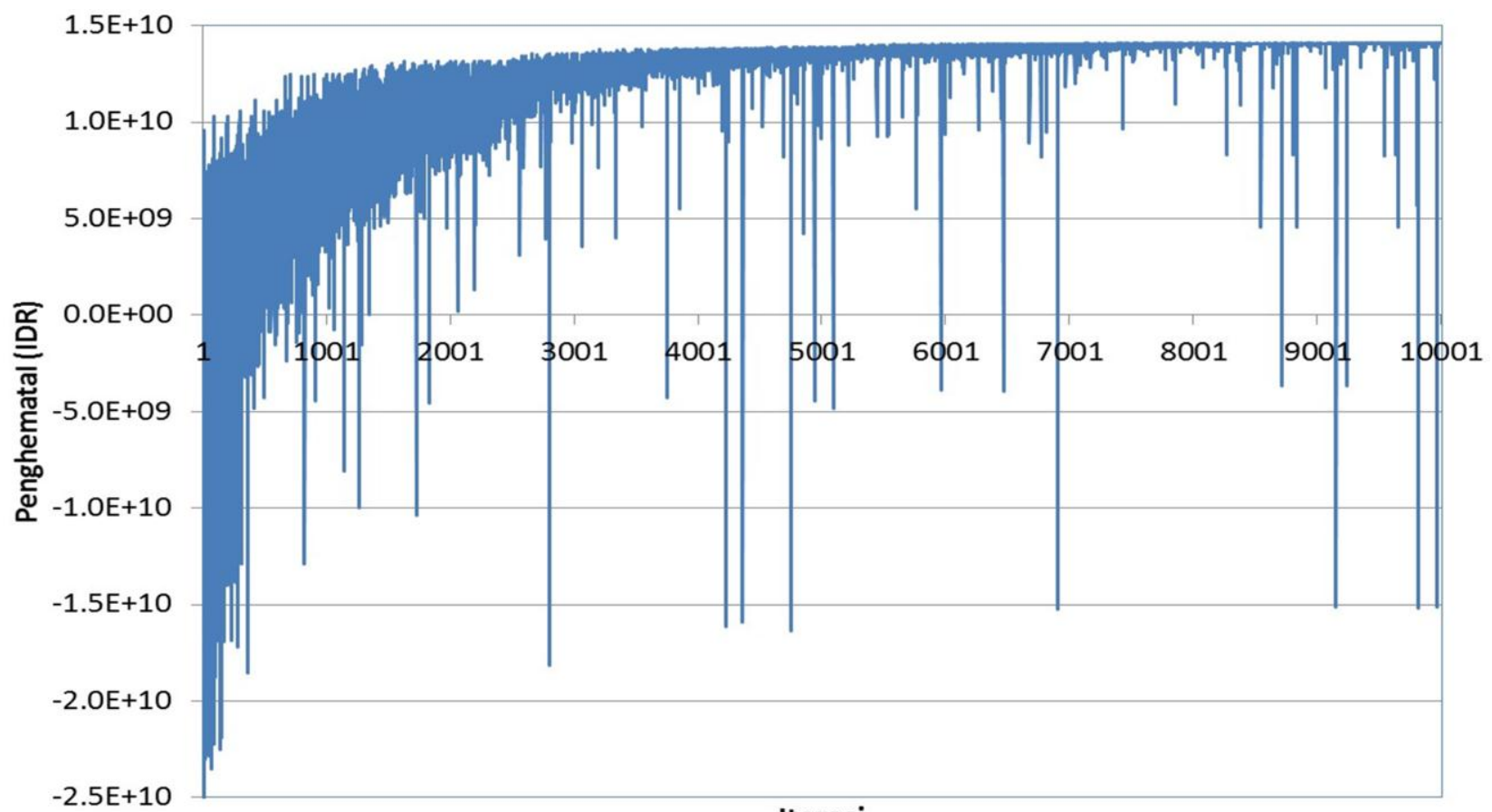

Gambar 2. Evolusi fitness pada kromosom sepanjang iterasi

Tabel 3. Energi yang diambil per penukar panas saat JPP terjadwal pembersihannya dengan optimal.

\begin{tabular}{|c|c|c|c|c|c|c|c|c|c|}
\hline \multirow[b]{2}{*}{$\begin{array}{l}\text { Nomer } \\
\text { penukar } \\
\text { panas }\end{array}$} & \multirow[b]{2}{*}{$\begin{array}{l}\text { Energi yang } \\
\text { diambil saat } \\
\text { kondisi bersih } \\
\text { (IDR) }\end{array}$} & \multirow[b]{2}{*}{$\begin{array}{c}\text { Energi yang } \\
\text { diambil saat } \\
\text { kondisi kotor } \\
\text { (IDR) }\end{array}$} & \multirow[b]{2}{*}{$\begin{array}{l}\text { Energi yang } \\
\text { hilang karena } \\
\text { kondisi kotor } \\
\text { (IDR) }\end{array}$} & \multicolumn{5}{|c|}{ Dalam kondisi pembersihan yang terjadual secara optimal } & \multirow[b]{2}{*}{$\begin{array}{l}\text { - Penghematan } \\
\text { karena optimasi } \\
\text { pembersihan } \\
\text { berkala pada } \\
\text { JPP (IDR) }\end{array}$} \\
\hline & & & & $\begin{array}{l}\text { Energi yang } \\
\text { diambil (IDR) }\end{array}$ & $\begin{array}{c}\text { Biaya } \\
\text { operasional } \\
\text { tambahan } \\
\text { untuk pompa } \\
\text { (IDR) }\end{array}$ & $\begin{array}{c}\text { Biaya } \\
\text { pembersihan } \\
\text { (IDR) }\end{array}$ & $\begin{array}{l}\text { Energi bersih } \\
\text { yang bisa } \\
\text { diambil (IDR) }\end{array}$ & $\begin{array}{l}\text { Energi yang } \\
\text { hilang saat } \\
\text { kondisi optimal } \\
\text { (IDR) }\end{array}$ & \\
\hline & & & & & & & & & \\
\hline E- & & & & & & & & & \\
\hline & & & & 17 & & & & & \\
\hline E-C & & & & 13 & & & & & \\
\hline & & & & & & 2.144 & 25.2 & & \\
\hline & & & & 165.486 & 641 & & & & \\
\hline & & & & & & & & & \\
\hline & & & & & & & & & \\
\hline & & & & 14.498.365.049 & 122.1 & & & & \\
\hline & 21.640.886.351 & 19.688.942.025 & 1.951.944.327 & 21.401.717.793 & 31.806 .477 & 1.372 .170 .240 & 19.997.741.076 & 45.276 & 99.051 \\
\hline & 38.458.004.705 & 14.878.041.696 & 23.579 .963 .009 & 14.970 .230 .811 & 342.274 .288 & 653.924 .880 & 13.974 .031 .643 & 24.483.973.062 & \\
\hline Total & 279.171 .808 .796 & 216.914.594.007 & 62.257 .214 .789 & 247.089 .182 .175 & 3.147 .822 .8511 & 12.878 .389 .440 & 231.062 .969 .884 & 48.108 .838 .912 & 14.148 .375 .877 \\
\hline
\end{tabular}

Penukar panas E-08 lebih banyak mengambil energi saat kondisi jadwal pembersihan optimal daripada saat kondisi bersih. Hal ini terutama disebabkan oleh LMTD yang tinggi pada penukar penukar panas ini, karena penukar panas lainnya mengalami fouling yang berat. Seperti yang terlihat pada Tabel 3, E-08 sendiri mampu memberikan penghematan bersih IDR 16 Milyar.

Pernukar panas E-10 memerlukan pembersihan 8 kali dan dapat mengurangi bersih dari dari IDR 1,97 Milyar ke IDR 1,64 Milyar dan menyebabkan keuntungan sebesar IDR 0,31 Milyar.

Semua penukar panas lainnya telah mengalami kerugian saat kondisi kondisi pembersihkan terjadwal secara optimal. Namun, pengaruh tidak langsung terhadap kinerja penukar panas lainnya telah menghasilkan penghematan bersih sampai IDR 14,1 Milyar.

Dapat diamati bahwa, hanya penukar panas E-01, E-05, E-08 dan E-10 yang mampu memberikan keuntungan saat dioptimasi. Hal ini membuktikan bahwa optimasi jadual pembersihan penukar panas pada JPP adalah masalah yang susah dipecahkan. Energi yang bisa diambil saat bersih, kotor dan jadual pembersihan teroptimasi dapat dilihat pada Gambar 3.

Gambar 3. menunjukkan jumlah energi yang bisa diambil saat kondisi bersih sebesar 80,1 GW dan di saat kotor 63,5 GW, yang mempuyai arti bahwa potensi energi yang masih mungkin bisa diambil dari 


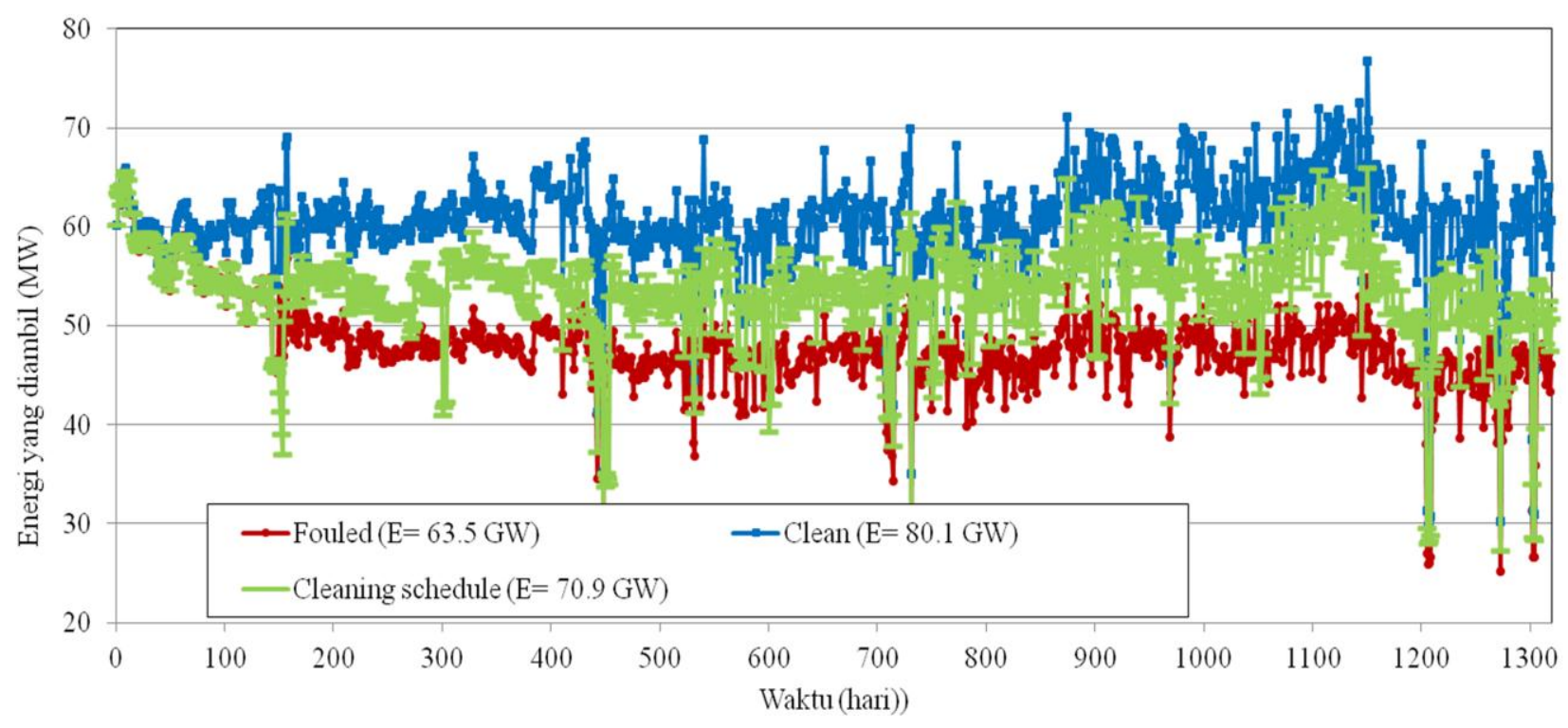

Gambar 3. Energi yang diambil saat bersih. kotor dan dengan jadwal pembersihan yang optimal.

JPP ini adalah sebesar 16.6 GW. Hasil optimasi menunjukkan bahwa dengan optimasi jadwal pembersihan yang optimal, maka terlihat hasil optimasi energi yang bisa diambil kembali adalah sangat dekat dengan nilai maksimum energi yang mungkin bisa diambil. Pengambilan energi kembali sebesar 70,9 GW telah dicapai dengan mengoptimasi jadwal pembersihan penukar panas pada JPE secara serentak. Pengambilan kembali energi ini tidak bisa mencapai pengambilan sepenuhnya disebabkan tujuan optimasi adalah pengehematan dalam IDR yang sebesar-besarnya, yang meliputi penghematan karena pengambilan energi kembali dikurangi biaya pembersihan, sesuai Persamaan (10)

Dari uraian di atas bisa digaris bawahi bahwa, sebuah masalah MINLP pada kasus optimasi jadwal pembersihan telah dirumuskan dan pemodelan penukar panas pada JPP telah dibangun bersama model prediksi fouling. Jumlah variabel optimasi sangat berkurang melalui penggunaan interval pembersih untuk masing-masing penukar panas. Secara alami dari masalah optimasi yang merupakan masalah MINLP yang susah dipecahkan dengan metode deterministik, telah dipecahkan dengan menggunakan metode metaheuristik yaitu GA sederhana. Penggunaan GA untuk memecahkan masalah optimasi tidak melibatkan perkiraan atau asumsi untuk menyederhanakan masalah. Terpenting adalah, sebagai salah satu metaheuristik, GA akan selalu memberikan solusi pada setiap akhir optimasi dan bisa dilanjutkan untuk mendapatkan solusi yang lebih optimal sampai hasil yang secara aplikasi bisa mendekati global optimum.

Dari optimasi yang dilakukan secara serempak/ simultan untuk semua penukar panas mengunakan
GA, dapat diamati bahwa pelaksanaan jadwal pembersihan yang optimal menghasilkan penghematan bersih sekitar IDR 14,1 Milyar atau peningkatan efisiensi $23 \%$ selama periode 44 bulan.

\section{Simpulan}

Dari penelitian ini dapat disimpulkan bahwa, sebagai salah satu algoritma metaheuristic, GA telah memberikan solusi pada optimasi jadual pembersihan secara simultan dan memastikan pencapaian mendekati global optimum dengan memberikan penghematan ekonomi sekitar IDR 14,1 Milyar dalam periode 44 bulan.

\section{Daftar Pustaka}

1. ESDU, Heat Exchanger Fouling in the Preheat Train of a Crude Oil Distillation Unit, ESDU, London 2000.

2. Yeap, B.L., Design of Heat Exchanger Networks with Fouling Mitigation, in CGPS Dissertation: University of Cambridge, UK, 2001.

3. Smaïli, F., Vassiliadis, V.S., and Wilson, D.I., Mitigation of Fouling in Refinery Heat Exchanger Networks by Optimal Management of Cleaning, Energy and Fuels, 15, 2001, pp. 1038-1056.

4. Georgiadis, M.C., Papageorgiou, L.G., and Macchietto, S., Optimal Cleaning Policies in Heat Exchanger Networks under Rapid Fouling, Industrial \& Engineering Chemistry Research, 39, 2000, pp. 441-454.

5. Lavaja, J.H., and Bagajewicz, M.J., On a New MILP Model for the Planning of Heat-Exchanger Network Cleaning, Industrial \& Engineering Chemistry Research, 43, 2004, pp. 3924-3938. 
6. Markowski, M., and Urbaniec, K., Optimal Cleaning Schedule for Heat Exchangers in a Heat Exchanger Network, Applied Thermal Engineering, 25, 2005, pp. 1019-1032.

7. Sanaye, S., and Niroomand, B., Simulation of Heat Exchanger Network (HEN) and Planning the Optimum Cleaning Schedule, Energy Conversion and Management, 48, 2007, pp. 14501461.

8. Georgiadis, M.C., Papageorgiou, L.G., and Macchietto, S., Optimal Cyclic Cleaning Scheduling in Heat Exchanger Networks under Fouling, Computers \& Chemical Engineering, 23, 1999, pp. S203-S206.

9. Ishiyama, E.M., Heins, A.V., Paterson, W.R., Spinelli, L., and Wilson, D.I., Scheduling Cleaning in a Crude Oil Preheat Train Subject to Fouling: Incorporating Desalter Control, Applied Thermal Engineering, 30, 2010, pp. 1852-1862.

10. Riverol, C., and Naopolitano, V., Estimation of Fouling in a Plate Heat Exchanger through the Application of Neural Networks, Journal of Chemical Technology and Biotechnology, 80, 2005, pp. 594-600.

11. Lalot, S., On-line Detection of Fouling in a Water Circulating Temperature Controller (WCTC) Used in Injection Moulding: Part 2: Application, Applied Thermal Engineering, 26, 2006, pp. 1095-1105.

12. Aminian, J., and Shahhosseini, S., Evaluation of ANN Modeling for Prediction of Crude Oil Fouling Behavior, Applied Thermal Engineering, 28, 2008, pp. 668-674.

13. Aminian, J., and Shahhosseini, S., Neuro-based Formulation to Predict Fouling Threshold in Crude Preheaters, International Communications in Heat and Mass Transfer, 36, 2009, pp. 525-531.

14. Smaill, F., Angadi, D.K., Hatch, C.M., and Herbert, O., Optimization of Scheduling of Cleaning in Heat Exchanger Networks Subject to Fouling: Sugar Industry Case Study, Food and Bioproducts Processing, 77, 1999, pp. 159-164.
15. Georgiadis, M.C., and Papageorgiou, L.G., Optimal Scheduling of Heat-integrated Multipurpose Plants under Fouling Conditions, Applied Thermal Engineering, 21, 2001, pp. 1675-1697.

16. Costa, L., and Oliveira, P., Evolutionary Algorithms Approach to the Solution of Mixed Integer Non-linear Programming Problems, Computers and Chemical Engineering, 25, 2001, pp. 257266.

17. Azzaro-Pantel, C., Bernal-Haro, L., Baudet, P., Domenech, S., and Pibouleau, L., A Two-stage Methodology for Short-term Batch Plant Scheduling: Discrete-event Simulation and Genetic Algorithm, Computers \& Chemical Engineering, 22, 1998, pp. 1461-1481.

18. Tayal, M.C., Fu, Y., and Diwekar, U.M., Optimal Design of Heat Exchangers: A Genetic Algorithm Framework, Industrial \& Engineering Chemistry Research, 38, 1999, pp. 456-467.

19. Cheema, J.J.S., Sankpal, N.V., Tambe, S.S., and Kulkarni, B.D., Genetic Programming Assisted Stochastic Optimization Strategies for Optimization of Glucose to Gluconic Acid Fermentation, Biotechnology Progress, 18, 2002, pp. 1356-1365.

20. Negnevitsky, M., and Kelareva, G., Application of Genetic Algorithms for Maintenance Scheduling in Power Systems, in International Conference on Neural Information Processing ICONIP '99, 2, 1999, pp. 447-452.

21. Syswerda, G., and Palmucci, J., The Application of Genetic Algorithms to Resource Scheduling, Fourth International Conference of Genetic Algorithm, San Mateo, CA, 1991, pp. 502-508.

22. Sim, L.M., Dias, D.M., and Pacheco, M.A.C., Refinery Scheduling Optimization using Genetic Algorithms and Cooperative Coevolution, in 6th WSEAS International Conference on Simulation, Modelling and Optimization, Lisbon, Portugal, 2007, pp. 151-158.

23. Guy, R.K., and Nelson, E.C. Jr, Refinery Scheduling of Incoming Crude Oil using a Genetic Algorithm, SA: US Patents, 2004.

24. Kern, D.Q., and Seaton, R.E., A Theoretical Analysis of Thermal Surface Fouling, British Chemical Engineering, 4(5), 1959, pp. 258-262. 